\title{
External Debt, Public Investment and Economic Growth in Cameroon
}

\author{
Forbe Hodu Ngangnchi ${ }^{1}$ and Roland Joefendeh ${ }^{2}$ \\ ${ }^{1}$ Department of Organisational Sciences, Higher Institute of Commerce and Management, \\ The University of Bamenda, Cameroon \\ ${ }^{2}$ Department of Economics, Faculty of Economics and Management Sciences, The University \\ of Bamenda, Cameroon \\ Corresponding author: email: chiefforbe@gmail.com
}

\begin{abstract}
This study investigates the extent to which external debt and public investment contributes to economic growth in Cameroon - emphasising on how public investment modulates the effect of external debt on economic growth. Time series data spanning the period 1980-2018 obtained from the World Bank's world development indicators are used, together with the Dynamic Ordinary Least Squares (OLS) approach to ascertain the nature of the long-run relationship between external debt, public investment and economic growth. Consistent with the debt-overhang and crowding-out literature, the study reveals a negative significant influence of external debt on economic growth in Cameroon. Results also reveal that there is a positive and significant direct effect of public investment on economic growth in the long run. Further results indicate that public investment and external debt positively and significantly engender economic growth. This is evidence that public investment is modulating the effect of external debt on economic growth in Cameroon. These findings suggest the need for developing country governments to create an enabling environment for private sector development, while accompanying external debt resources with domestic revenue mobilization by broadening the tax base - taxes on landed property being potential candidates.
\end{abstract}

Key words: External debt, Public investment, Economic growth, DOLS.

\section{How to Cite:}

Ngangnchi, F. H., and Joefendeh, R. (2021). External Debt, Public Investment and Economic Growth in Cameroon. International Journal of Finance Research, 2(4). 260 - 273. DOI: https://doi.org/10.47747/ijfr.v2i4.461

\section{Introduction}

Economic growth and development remains a major concern of most developing countries; to solve this problem, resources are mobilized from various sources including external borrowing for investment into productive projects for growth acceleration. Sustainable economic growth is the prime concern for all countries, especially developing economies that frequently face burgeoning fiscal deficits mainly driven by higher levels of debt service, particularly external debt servicing and widening current account deficits (Bernardin et al, 2018). The Harrod-Domar growth model has been the source of inspiration for development 
economists in explaining the importance of external borrowing in closing the savingsinvestment gap in developing countries.

The principal reason for governments borrowing is to finance public goods that increase welfare and promote economic growth. The spending has to be financed either through taxation, through seignorage, or with debt. Theoretically, it is expected that developing countries would benefit from external borrowing if the marginal product of capital is higher than the world interest rate (Ogunmuyiwa, 2011).

According to Atigue and Malik (2012), many poor countries become poorer after taking foreign assistance from rich international creditors such as the World Bank, the IMF and the Paris Club have been negligent towards the risk of poverty trap for low income countries.

According to World Bank (2019), Cameroon's total external debt in 2016 was \$8,186 million and increased to $\$ 10,396$ million in 2017 . This shows an increase of $\$ 2210$ million between 2016 and 2017. It has been observed that Public debt in Cameroon has gradually and steadily increased since the debt relief under the enhanced Heavily Indebted Poor Countries (HIPC) and Multilateral Debt Relief Initiatives (MDRI). Total public sector debt (external plus domestic public debt) increased threefold since 2010 to 35.2 percent of GDP in 2016, with about 70 percent of the increase driven by a surge in public and publicly guaranteed (PPG) external debt. The increase in public debt in Cameroon during 2009-2015 (25 percentage points of GDP) was more than double the median for SSA countries (12 percentage points of GDP).

Cameroon's budget for 2019 stood at 4850.5 billion FCFA and 4951.7 billion in 2020 . There is an increase of 161 billion or 3.43 percent of the budget of 2019, compared to the previous year budget. The expectation of the government is for the GDP to grow further from 0.9 percent in 2019, to 4.4 percent in the upcoming year (Hugue, 2018). Between 2006 and 2016, public expenditures have increased substantially in Cameroon, the country's total public spending rose substantially from 13 percent of GDP in 2006 to 21 percent of GDP in 2016. This increase financed some of the Vision 2035 and GESP goals, resulting in an increased capital expenditure from 2.6 percent in 2006 to 7.9 percent of GDP in 2016. Over the last decade, the share of capital expenditures in Cameroon's total public expenditure has increased considerably particularly since 2010 . This is as a result of the fact that authorities increased public investments to meet the Vision 2035, GESP and Plan d'Urgence Triennal (PLANUT) goals. Between 2006 and 2009, public spending increased by 2.6 percent of GDP. That is from 13.2 percent of GDP in 2006 to 15.7 percent of GDP in 2009 (World Bank, 2018).

Before 1978, Public investment as a ratio to GDP was 2.4\%. Between 1978 and 1986, public investments as a ratio of GDP increased to $10.5 \%$. The increase in public investment is explained by the developmental strategy adopted by the government to expand the public sector (Njimanted and Mukete, 2013).

The Growth and Employment Strategy Paper (GESP) 2009 and Vision 2035 (2009) outlined Cameroon's main strategic and long-term goals. In order for Cameroon to achieve its development objective, closing the infrastructure gap is imperative. Since 2000, growth has averaged 3.6 percent which remains well below the 5.5 percent average target rate in the GESP for 2010-20. This potential growth could come from solving infrastructural challenges in power supply by lowering production costs and increasing national access rates, and in 
transport services by improving road conditions and transport costs along the main transit corridors to neighboring countries (IMF, 2014).

Since independence in the 1960s, a lot has been done by the government of Cameroon to foster economic growth and development. Among many of such measures are; the five-year economic and social development plan in 1961 to re-enforce and guarantee sustainable growth of the national economy in terms of increase in real gross domestic product (GDP), the introduction of the Structural Adjustment Programme (SAP) in 1988/1989, followed by the devaluation of the FCFA in 1994 after the deduction of civil servants' salaries by over 50 percent. Between the period 1970 and 2003, the total external debt of Cameroon increased from 14.23 percent to 96.3 percent of Gross Domestic Income. But as from 2005, it began to reduce gradually due to progress in the debt reduction; rescheduling and cancellation initiative by the donor community. In 2008, the external debts Cameroon owed the respective donors were only about 1.438 billion US dollar, close to 50 percent reduction from the 1980 s levels. The average Gross domestic product (GPD) of Cameroon in real terms has been on the increase since 1970 . The real gross domestic product by 1980 was 1410 billion FCFA and by 2008, it stood at some 2840 billion FCFA (Njimanted et al, 2015).

The trend of Cameroon's external debt has shown an increasing pattern in recent years. Statistics show that the external debt to GDP ratio of Cameroon in actual terms stands at 21.6 percent in 2015, 25.4 percent in 2016 and 28.2 percent in 2017. Projections show that it will rise to about 29.9 percent in 2019 and then falls gradually to about 23.0 percent in 2038 (IDA and IMF, 2018).

The annual GDP growth rate slowed to 3.2 percent in 2017, the lowest rate in seven years, and the fiscal deficit peaked at 6.1 percent in 2016. Meanwhile, a significant increase in borrowing to fund large infrastructure projects pushed the debt-to-GDP ratio from 15.9 percent of GDP in 2006 to 35.7 percent of GDP in 2017. Between 1986 and 2009, public investment averaged 1.5 percent of GDP even though it is less than half the average for regional comparators (4.1 percent of GDP) and global comparators (3.4 percent of GDP). Between 2011 and 2015, the government of Cameroon boosted capital spending significantly in laudable attempt to narrow its infrastructure gap. Also, public investment increased substantially between 2012 and 2015 from 792.2 billion FCFA to 1150 billion FCFA, respectively (World Bank, 2018).

The concrete reason for a country to contract debt is to invest in productive projects for growth acceleration. According to World Bank (2019), Public debt in Cameroon has gradually and steadily increased since the debt relief under the enhanced Heavily Indebted Poor Countries (HIPC) and Multilateral Debt Relief Initiatives (MDRI).In the same way, World Bank (2018) report shows that between 2006 and 2016, public expenditures have increased substantially in Cameroon, the country's total public spending rose substantially from 13 percent of GDP in 2006 to 21 percent of GDP in 2016. This increase financed some of the Vision 2035 and GESP goals, resulting in an increase capital expenditure from 2.6 percent in 2006 to 7.9 percent of GDP in 2016. The foregoing issues raised bring us to the focal point of this research work which is to examine the extent to which external debt and public investment contributes to economic growth in Cameroon. The study is expected to give results that indicate the effect that exists between external debt and public investments on economic growth. 


\section{Literature Review}

This paper is grounded in the following economic theories:

\section{The Harrod-Domar Growth Model}

This model was formulated separately by the British economist Roy Harrod and the American economist of Polish origin Evsey Domar in 1939 and 1946 respectively. Their results were so close to each other that it subsequently became known in scientific circle as the theory of Harrod-Domar. This model explains the place of saving and investment in economic growth.

In the technical conditions of production, economic growth is determined by the marginal propensity to save, and the dynamic equilibrium in the market system is inherently unstable, so that maintaining it at full employment requires active and purposeful actions of the state.

To illustrate the Harrod-Domar growth model, let savings (S) be some proportions, of national income $(Y)$ such that:

$\mathrm{S}=\mathrm{sY}$.

Investment (I) is defined as the change in capital stock, $\mathrm{K}$, and can be represented by DK such that $\mathrm{I}=\mathrm{DK}$. Total capital stock, $\mathrm{K}$, is directly related to national income, $\mathrm{Y}$, as represented by the capital-output ratio, $\mathrm{k}$, such that: $\mathrm{K} / \mathrm{Y}=\mathrm{k}$.

This capital-output ratio can also be written in its marginal value as

$\mathrm{DK} / \mathrm{DY}=\mathrm{k}$.

which is popularly known as the incremental capital-output ratio. Since the equilibrium saving, S, must equal total investment, I, it follows that $\mathrm{sY}=\mathrm{kDY}$ or in a more familiar expression,

$\mathrm{DY} / \mathrm{Y}=\mathrm{s} / \mathrm{k}$.

This equation reveals that the rate of growth of output is determined jointly by the national savings ratio, s, and the national capital output ratio, $\mathrm{k}$. It also says that the growth rate of national income will be directly related to the saving ratio and inversely related to capital output ratio.

In the context of this study, $\mathrm{Y}$ in the model represents economic growth while $\mathrm{k}$ represents public investment. According to Vision 2035, the savings level of Cameroon is low and stands at 17.4 percent of GDP which is a major hindrance to long term growth and development. The Harrod-Domar growth model suggests that for economic growth to occur, the rate of savings must be positive and rising. Since most developing countries have a negative attitude towards savings, they always resort to borrow in order to complement the domestic savings for economic growth. Since savings in Cameroon is low, the Harrod-Domar model sees borrowing to be complementary to domestic savings which is seen as an engine to economic growth.

In other to situate this paper within relevant context, the following peer reviews are consulted, stating with: Atique and Malik (2012) show the existence of an inverse relationship between domestic debt and economic growth and between external debt and economic growth in Pakistan. Kharusi and Ada (2018) also find that external debt has a negative significant effect on economic growth in Oman. Their findings are similar even though with use of different 
methodologies. Furthermore, Onakoya and Ogunade (2017) conducted a research and found that external debt is negatively related to economic growth. In like manner, Ogunmuyiwa (2011) using Vector error correction Method (VECM) show that the is no strict causality between external debt and economic growth in Nigeria

Asghar (2016) found that economic growth is significantly explained by external debt in a time series study carried out in Pakistan. Also, Elwasila (2018) in Sudan, find a positive effect of external debt on economic growth. Furthermore, Saifuddin Md (2016) using Two Stage Least Square as an estimation technique show that public debt positively affect economic growth in Bangladesh.

Using both fixed effects and system General Method of Moments (GMM) to estimate data collected from 55 low-income countries that are classified as eligible for the IMF's Poverty Reduction and Growth Facility (PRGF). Benedict et al (2003) observed that, beyond a certain limit, higher external debt is associated with lower rates of growth of per capita income. The data used in this study cover a period of 29 years (1970-99). Meanwhile Mahmud and Shahida (2012) found a significant long run negative effect of external public debt service in Bangladesh.

Servicing higher external debt as a result of growing external debt stock consumes much of the fiscal revenues and leaves lesser revenue with the fiscal authorities to run the economy. Hence, developing countries in order to meet up with this gap, either try to borrow more resources from abroad to maintain economic stability or cut down their capital expenditure, which in turn affect the economic growth. To validate this hypothesis, Shabir (2013) used linear panel data from a sample of 70 developing countries for 36 years $(1976-2011)$ and obtained results which show an inverse relationship between external debt to GNI and growth rate of per capita GNI for the developing countries.

Like Ndubuisi (2017) who found a positive significant of effect external debt stock on Nigeria's growth index, Abuzaid (2011) in analyzing the impacts of external debt and debt services on growth and investment in three selected Arab countries Tunisia, Egypt and Morocco using two equations confirmed that, external debt affect growth directly. Also, the results indicate that external debt affects investment positively and is statistically significant.

Bernardin et al, (2018) examines the effect of external debt on economic growth in SubSaharan Africa (SSA) in view of an upsurge in the level of external debt in many countries on the continent. They concluded that, external debt negatively affects economic growth in SSA. In the same manner, Ncanywa and Masoga (2018) arrive at the conclusion according to which public debt is inversely related to economic growth.

Onakoya and Ogunade (2017) conducted a research and found that external debt is negatively related to economic growth. In like manner, Ogunmuyiwa (2011) using Vector error correction Method (VECM) show that the is no strict causality between external debt and economic growth in Nigeria

Njimanted et al (2015) used the system estimation approach in a study on "External debt, Domestic investment and economic growth" in Cameroon over the periods 1980 to 2013. Using Two Stage Least Square as an estimation technique, the results they obtained revealed that external debts adversely affect economic growth in Cameroon. 
Much has been said under this topic since many have written under this area of external debt and economic growth with different results arrived at. It imperative to note that external debt left on its own without operating through other variables cannot bring about economic growth, but it must operate through other variables to produce the required result. This study looks at public investment as one of the mediums through which external debt operates to produce the required result.

\section{Research Methods}

This paper adopts the causal research design because it plays an instrumental role in terms of assessing the impacts of changes in existing norms and processes. The data used are quantitative in nature and are secondary. The adoption of a causal research design is justified by the fact it allows for the investigation of the cause and effect relationship between the variables of interest.

Three economic growth multivariate models are specified to determine the relationship and to address all three specific objectives of the paper.

The first model of this paper examines the effect of external debt (XDEBT) on economic growth. Econometrically specification as follows:

$$
\begin{aligned}
& G D P P C_{t}=\beta_{0}+\beta_{1} X D E D T_{t}+\beta_{2} P_{N} V_{t}+\beta_{3} D C P S_{t}+\beta_{4} B_{7} M O N_{t}+\beta_{5} E X P_{t}+\beta_{6} L F P_{t}+
\end{aligned}
$$

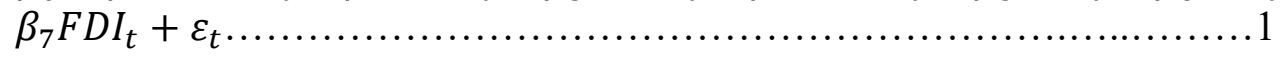

The second objective of the paper investigates the effect of public investment (GINV) on economic growth. The econometric model to address this second objective is formulated as follows:

$$
\begin{aligned}
& G D P P C_{t}=\alpha_{0}+\alpha_{1} G I N V_{t}+\alpha_{2} P I N V_{t}+\alpha_{3} D C P S_{t}+\alpha_{4} B M O N_{t}+\alpha_{5} E X P_{t}+\alpha_{6} L F P_{t}+
\end{aligned}
$$

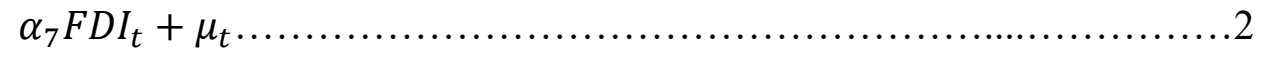

In order to examine the modulating effect of public investment on external debt on economic growth in Cameroon, the following model with interaction variable between external debt and public investment $(\mathrm{GINV} * \mathrm{XDEBT})$ is thus specified as:

$$
\begin{aligned}
& G D P P C_{t}=\gamma_{0}+\gamma_{1} X D E B T_{t}+\gamma_{2} G I N V_{t}+\gamma_{3} G I N V_{t} * X D E B T_{t}+\gamma_{4} P I N V_{t}+\gamma_{5} D C P S_{t}+
\end{aligned}
$$

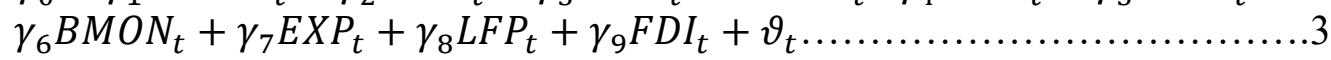

GDPPC is per capita GDP which is used here as a proxy for economic growth, XDEBT is external debt, GINV is public or government investment, PINV is private investment, DCPS is domestic credit to the private sector, BMON is broad money which captures money supply, EXP is exports, LFP is labour force participation rate, FDI is foreign direct investment, $\varepsilon_{t}, \mu_{t}$ and $\vartheta_{t}$ are the disturbance terms which is assume to follow a normal distribution. 
GDP per capita is included in the model because it is a better measure of economic growth while external debt on its own cannot produce the required result. Thus, public or government investment is the mechanism through which external debt operate to produce the expected result. With the inflow of foreign capital in the form external debt, broad money increases and as such it is imperative to see how it affects economic growth. With all these in play, exports are supposed to increase and the increase in exports supposed to correlate with growth. All these variables cannot operate without the participation of labour force.

Assuming a log-log model, we interpret the coefficients as elasticities. In this context, equations 1,2 and 3 become equations 4,5 and 6 respectively as:

$$
\begin{aligned}
& L G D P P C_{t}=\beta_{0}+\beta_{1} L X D E D T_{t}+\beta_{2} L P I N V_{t}+\beta_{3} L D C P S_{t}+\beta_{4} L B M O N_{t}+\beta_{5} L E X P_{t}+
\end{aligned}
$$

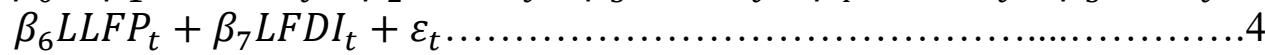

$$
\begin{aligned}
& L G D P P C_{t}=\alpha_{0}+\alpha_{1} L G I N V_{t}+\alpha_{2} L P I N V_{t}+\alpha_{3} L D C P S_{t}+\alpha_{4} L B M O N_{t}+\alpha_{5} L E X P_{t}+
\end{aligned}
$$

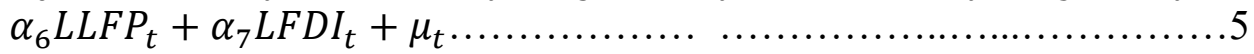

$$
\begin{aligned}
L G D P P C_{t}= & \gamma_{0}+\gamma_{1} L X D E B T_{t}+\gamma_{2} L G I N V_{t}+\gamma_{3} L G I N V_{t} * X D E B T_{t}+\gamma_{4} L P I N V_{t}+ \\
& \gamma_{5} L D C P S_{t}+\gamma_{6} L B M O N_{t}+\gamma_{7} L E X P_{t}+\gamma_{8} L L F P_{t}+\gamma_{9} L F D I_{t}+\vartheta_{t} \ldots \ldots \ldots 6
\end{aligned}
$$

Where $\beta_{1}$ to $\beta_{7}, \alpha_{1}$ to $\alpha_{7}$ and $\gamma_{1}$ to $\gamma_{9}$ are the coefficients of LGINV, LXDEBT, L(GINV* $X D E B T$ ), LPINV, LDCPS, LBMON, LEXP, LLFP and LFDI that is giving the percentage change in GDP per capita resulting from a unit percentage change in one of the explanatory variables holding any other variable constant. $\alpha_{0}, \beta_{0}$ and $\gamma_{0}$ are the constant term which can be considered here as the natural rate of economic growth in Cameroon.

For estimation of the parameters of the models specified, the Dynamic Ordinary Least Squares (DOLS) estimation technique was used. In fact, one of the key and strong assumptions of OLS estimation technique is the absence of correlation between the residuals and the explanatory variables $(\operatorname{Cov}(\varepsilon t, x t)=0)$. When this assumption is violated, the estimated parameter is bias and inconsistent, leading to a spurious regression. When it is postulated that there may be a significant correlation between the explanatory variable and the error term, this explanatory variable is no longer considered to be exogenous but rather endogenous. This problem is known in the econometric jargon as the problem of endogeneity. This is usually the case in time series data which are not stationary at level and are cointegrated as it is the case in the present study.

In effect, Stock and Watson (1993) showed that due to the fact that a linear combination of the dependent variable and independent variables create a stationary error term then this error term is correlated with the regressors (problem of endogeneity). One and most popular way of addressing this problem is that of using instrumental variables two stage least squares (2 SLS). One robust way of addressing this issue of endogeneity without using instrumental variables is the Dynamic OLS approach. The Dynamic OLS involves augmenting a (super consistent) OLS estimate of the co-integrating relationship with first differences of leads and lags of the right hand side (RHS) variable of the model specification (regressors). In this study 
our main variables are public investment and external debt. Stock and Watson (1993) proposed that in case of endogeneity of co-integrating variable and small sample bias as it is the case, the Dynamic OLS is preferable.

\section{Finding and Discussion}

To ensure results were appropriate, stationarity test was conducted since most economic time series variables are non-stationary and the use of non-stationary time series data leads to an apparent but not actually valid regression which implies that it cannot be used for precise decision. Testing for stationarity of the variables used in the models are non-stationary at levels but achieved stationarity after their first difference as seen from the unit roots test ( Augmented Dickey Fuller tests ) which therefore implies that all the variable are integrated of first order (I(1)).

Table 1. Dynamic OLS results of determinants of economic growth

\begin{tabular}{|c|c|c|c|}
\hline VARIABLES & $\begin{array}{l}\text { (1) } \\
\text { lgdppc }\end{array}$ & $\begin{array}{l}2) \\
\text { lgdppc }\end{array}$ & $\begin{array}{l}3) \\
\text { lgdppc }\end{array}$ \\
\hline 1xdebt & & $\begin{array}{l}-0.368 * * * \\
(0.0200)\end{array}$ & $\begin{array}{l}-3.700 * * * \\
(0.851)\end{array}$ \\
\hline lginv & $\begin{array}{l}0.211 * * * \\
(0.0268)\end{array}$ & & $\begin{array}{l}-2.966^{* * * *} \\
(0.736)\end{array}$ \\
\hline lginv_lxdebt & & & $\begin{array}{l}0.138 * * * \\
(0.0321)\end{array}$ \\
\hline lpinv & $\begin{array}{l}-0.0184 \\
(0.0170)\end{array}$ & $\begin{array}{l}0.230 * * * \\
(0.0309)\end{array}$ & $\begin{array}{l}0.0500^{* *} \\
(0.0244)\end{array}$ \\
\hline lbmon & $\begin{array}{l}0.199 * * * \\
(0.0403)\end{array}$ & $\begin{array}{l}0.0336 \\
(0.0280)\end{array}$ & $\begin{array}{l}0.238 * * * \\
(0.0265)\end{array}$ \\
\hline dcps & $\begin{array}{l}0.00601 * * * \\
(0.00109)\end{array}$ & $\begin{array}{l}0.00186 \\
(0.00155)\end{array}$ & $\begin{array}{l}-0.00130 \\
(0.00167)\end{array}$ \\
\hline lexp & $\begin{array}{l}-0.0726 * * * \\
(0.0243)\end{array}$ & $\begin{array}{l}0.210 * * * \\
(0.0618)\end{array}$ & $\begin{array}{l}-0.0448 * * * \\
(0.0138)\end{array}$ \\
\hline lfp & $\begin{array}{l}0.0115 * * * \\
(0.00115)\end{array}$ & $\begin{array}{l}0.0957 * * * \\
(0.00635)\end{array}$ & $\begin{array}{l}0.0380 * * * \\
(0.00799)\end{array}$ \\
\hline lfdi & $\begin{array}{l}-0.00496 * * * \\
(0.00184)\end{array}$ & $\begin{array}{l}0.0151 * * * \\
(0.00556)\end{array}$ & $\begin{array}{l}0.00203 \\
(0.00404)\end{array}$ \\
\hline F3D.lginv & $\begin{array}{l}0.0644 * * * \\
(0.0228)\end{array}$ & & $\begin{array}{l}0.0338 \\
(0.0234)\end{array}$ \\
\hline F2D.lginv & $\begin{array}{l}0.0306 \\
(0.0324)\end{array}$ & & $\begin{array}{l}-0.0213 \\
(0.0262)\end{array}$ \\
\hline FD.lginv & $\begin{array}{l}0.175 * * * \\
(0.0262)\end{array}$ & & $\begin{array}{l}0.0912 * * * \\
(0.0186)\end{array}$ \\
\hline D.lginv & $\begin{array}{l}-0.0358 * * \\
(0.0173)\end{array}$ & & $\begin{array}{l}-0.0248 \\
(0.0199)\end{array}$ \\
\hline LD.lginv & $\begin{array}{l}0.00666 \\
(0.0168)\end{array}$ & & $\begin{array}{l}0.0703 * * * \\
(0.0139)\end{array}$ \\
\hline
\end{tabular}




\begin{tabular}{llll}
\hline & $(1)$ & $(2)$ & $(3)$ \\
VARIABLES & $\operatorname{lgdppc}$ & $\operatorname{lgdppc}$ & $\operatorname{lgdppc}$ \\
\hline L2D.lginv & $0.0916^{* * *}$ & & $0.0678^{* * *}$ \\
& $(0.0216)$ & & $(0.0107)$ \\
L3D.lginv & $0.0542^{* *}$ & & $0.0481^{* * *}$ \\
& $(0.0224)$ & & $(0.0153)$ \\
F3D.lxdebt & & $0.0561^{* * *}$ & $0.0594^{* * *}$ \\
& & $(0.0196)$ & $(0.0202)$ \\
F2D.lxdebt & & $-0.0396^{* * *}$ & -0.00313 \\
& & $(0.0153)$ & $(0.00813)$ \\
FD.lxdebt & & -0.0222 & $0.0318^{* * *}$ \\
& & $(0.0148)$ & $(0.00408)$ \\
D.lxdebt & & $0.331^{* * *}$ & $0.115^{* * *}$ \\
& & $(0.0275)$ & $(0.0278)$ \\
LD.lxdebt & & $0.410^{* * *}$ & $0.146^{* * *}$ \\
& & $(0.0225)$ & $(0.0448)$ \\
L2D.lxdebt & & $0.215^{* * *}$ & $0.0401^{* * *}$ \\
& & $(0.0220)$ & $(0.00995)$ \\
L3D.lxdebt & & $0.155^{* * *}$ & $0.0666^{* * *}$ \\
& & $(0.0213)$ & $(0.0244)$ \\
Constant & $8.724^{* * *}$ & 1.333 & $89.09^{* * *}$ \\
& $(0.914)$ & $(0.992)$ & $(19.05)$ \\
& & 32 & 32 \\
Observations & 32 & 0.974 & 0.996 \\
R-squared & 0.992 & &
\end{tabular}

Note: Standard errors in parentheses, $* * * \mathrm{p}<0.01, * * \mathrm{p}<0.05, * \mathrm{p}<0.1$

Source: Computed by authors (2021)

All three models are globally significant at $1 \%$ given a probability value of $\mathrm{Chi}^{2}$ (Prob > chi2 $=0.0000$ ) which is below 0.01 and, between $97.4 \%$ and $99.6 \%$ of variations in economic growth in the long run is explained by a joint variation of all the regressors included in the model.

Results from Table 1, indicate that the coefficient of public investment is positive $(0.211)$ which implies that there is a positive long run effect of public investment on economic growth in Cameroon. In effect, an increase of government or public investment by one percent will lead to an increase in GDP per capita by about $0.21 \%$ everything being equal in the long run. It should be noted that this result is significant at $1 \%$ level. Thus there is a positive and significant effect of government investment on economic growth in Cameroon in the long run. This result is in line with a priori expectation and confirms the Barro (1990) model of endogenous growth which posits that proper and quality government spending geared towards infrastructure development will result in economic growth. This result also confirms the Keynesian theory of economic growth, which acknowledges investment, especially public investment, as the main driver of economic growth through the multiplier effect. If public investment is carried out to improve the quality of infrastructure, this will reduce the cost of 
private investment and increase the return to investment and by so doing spur economic growth. This result is in conformity with the finding of Ouattara (2004) who found a positive effect on government investment on economic growth.

Column 2 of Table 1 indicates that the coefficient of external debt is negative $(-0.368)$ meaning that external debt relates negatively with economic growth measured by per capita GDP in the long run in Cameroon. A unit percentage increase in the total external debt stock by one percent will result in about $0.37 \%$ fall in economic growth ceteris paribus. This finding is significant at $1 \%$ level. This outcome confirms the debt overhang hypothesis which indicates that accumulated debt stock reduces economic performance through what the proponents of this theory called "debt overhang" effect including tax disincentive especially on private sector investment as macroeconomic instability signals. This hypothesis makes it clear that with very high level of external debt, the government has no incentive to carry out macroeconomic reforms and good policies as such the prevalence of poverty. Since the return of these reforms will only be used to repay outstanding debt. This result is in line with the findings of Bernardin et al, (2018), Njimanted et al. (2015) and Atique and Malik, (2012) who found a negative effect of external debt on economic growth, but contradicts the finding of Elwasila (2018) in Sudan who rather found a positive relationship between external debt and economic growth.

When taking into consideration the possible modulating effect of public investment on the effect of external debt on economic growth (Column 3), results reveal that there is positive modulating effect of public investment on the effect of external debt on economic growth in Cameroon in the long run given that the coefficient of the interaction variable between public investment and external debt is positive whereas the coefficient of external debt and public investment are negative. More precisely, results from the DOLS, show that the negative effect of external debt on economic growth is significantly watered down by public investment. This finding is significant at $1 \%$ level. Thus, there is a significant positive influence of public investment on the effect of external debt on economic growth in Cameroon in the long run. . This positive modulating effect conforms to the finding of Ncanywa and Masoga (2018) who also found that public investment could help mitigate the negative effect of external debt on economic growth. This finding therefore shows that, if the external debt is properly used to create favourable conditions for private investment such as constructing road, hospitals, schools and training centres, improving on the communications network and other transport facilities, this will go a long way to improve on the effectiveness of external debt on less developed economies such as Cameroon.

Going by the control variables, results reveal that there is a positive and significant relationship between private sector investment and economic growth in Cameroon. In other words, the higher the level of investment by the private sector, the higher will be the level of gross domestic product in Cameroon. This result conforms to our prior expectation and falls in line with the result of Kongphet and Masaru (2012), who found a positive relationship between investment and economic growth. Higher level of investment by the private sector may translate into more employment and more income to the population due to remuneration of factors of production.

In addition, money supply measured by broad money consistently exerts a positive effect on economic growth given that the coefficient of broad money (BMON) is positive across all the specifications. This result signifies that an increase in money supply will bring about an 
increase in per capita gross domestic income in the long run. This result is significant at $1 \%$ level in Columns 1 and 3, but insignificant in Column 2. Thus, money supply is relevant for policy recommendations aimed at improving the economic growth in Cameroon. This confirms with Prasert Chaitip et al. (2015) who found that money supply were associated with economic growth.

Similarly, the coefficient of domestic credit to the private sector (DCPS) is positive in Columns 1 and 2 but negative in Column 3 - implying a positive effect of credit availability or financial development on the economic growth. But when accounting for the modulating effect of public investment on external debt, this effect is reversed. However, it should be noted that only the coefficient of DCPS in Column 1 is statistically significant. This result is in accordance with Olowofeso et al (2015) who confirmed a positive and significant effect of private sector credit on output.

Further results reveal that there is a consistent positive and significant effect of labour force participation (LFP) on economic growth. The coefficients of LFP are positive across all three specifications and significant at $1 \%$ level. On average, an increase of labour force participation by one percent will result in about $0.04 \%$ increase in per capita income in Cameroon everything else held constant. The result obtained at this level is contrary to Shahid (2014) who found that labour force participation has negative significant effect to economic growth.

\section{Conclusion}

The result did not confirm a positive relationship between external debt and growth. Thus, there is a negative significant relationship between external debt and growth in the long run. Investment is a vital ingredient of economic growth to less developed countries; the coefficient of public investment is positive and has a statistically significant effect on economic growth in the long run. This means that a substantial part of the country GDP has been invested and that helped her to grow quickly. A significant influence of public investment on the effect of external debt on economic growth was established in the result. The moderating effect of public investment on external debt to economic growth was found to be significant and positive. This indicates that public investment influences external debt positively on economic growth. This implies that public investment change the negative effect of external debt on economic growth to positive.

Based on the empirical findings, the following policy outcomes are proposed:

The governments should ensure that the foreign loans are invested in projects that would eventually generate enough returns to amortize the debt. Also, enhancing domestic revenue mobilization will go a long way to reduce over reliance on external financing. In this regard, there is the need to embark on efficient revenue mobilization drives through the broadening of tax base, devising various strategies to capture untaxed informal sectors into the tax net and check revenue leakages so as to increase domestic revenue mobilization.

For debt to promote growth in Cameroon, fiscal discipline and high sense of responsibility in handling public funds should be the watchword of the leaders. 
Furthermore, the government should increase the effective and appropriate utilization of external resources by investing in selected productive investment including basic infrastructural developments that facilitate the productivity of other sectors of the economy.

Also it is suggested that governments should pay more attention to proper debt management, to items of expenditure and try to direct it to productive use. The government should cut down the contraction of new debts while investing the already contracted debt as well as debt relief funds in the real sector of the economy.

Investments should be directed in real sectors of the economy such as the agricultural, infrastructure, industrial, education, energy and health which will act as catalyst for the national development.

Investment in education should be encouraged given that the coefficient of labour force participation is positive and significant in the long run. Education that provides the technical know-how should be encouraged as this contributes significantly to the growth of the economy. As such, investment in technical education, creation of Universities for science and technology throughout the national territory alongside polytechnics are strongly recommended.

\section{References}

Abuzaid L. E. M. (2011). External debt, economic growth and investment in Egypt, Morocco and Tunisia (unpublished). University of Gloucestershire.

Asghar M. S. (2016). The effect of external debt in the economic growth of Pakistan. Journal for Studies in Management and Planning.Vol.02, e-ISSN: 2395-0463

Atique R. and Kamran M.(2012) .Impact of Domestic and External Debt on the Economic Growth of Pakistan. World Applied Sciences Journal, 20 (1): 120-129.

Barro R. J.( 1990). Government spending in a simple model of endogenous growth. Journal of Political Economy 98(S5): 103-125

Benedict C., Bhattacharya R., and Nguyen T. Q. (2003). External Debt, Public Investment, and Growth in Low-Income Countries. International Monetary Fund Working Paper, (WP/03/249).

Bernardin, S., Fiagbe, Agbemavor Korsi; Quartey, Peter (2018). The effect of external debt on economic growth in Sub-Saharan Africa. International Journal of Business and Economic Sciences Applied Research (IJBESAR), Vol. 11, pp. 61-69.

Elwasila S. E. M. (2018). Effect of External Debt on Economic Growth of Sudan: Empirical Analysis (1969-2015). Journal of Economic Cooperation and Development, Vol. 39, pp. 39-62.

Hugue, N. (2018). Report on Cameroon's 2019 Budget (unpublished). University of Bath.

International Development Association and International Monetary Fund (2018). Cameroon: Joint Bank-Fund Debt Sustainability Analysis.

International Monetary Fund (2014). Cameroon: Selected Issues 
Kharusi S. A and Ada M. S, (2018). External Debt and Economic Growth: The Case of Emerging Economy. Journal of Economic Integration.Vol.33, pp.1141-1157.

Kongphet P. and Masaru I. (2012), The Impact of Public and Private Investment on Economic Growth: Evidence from Developing Asian Countries IDEC Discussion paper 2012. Hiroshima Universityi, Hiroshima 739-8529, Japan.

Mahmud H. S. and Shahida P. (2012). External Public Debt and Economic Growth: Empirical evidence from Bangladesh, 1974 To 2010. Academic Research International, Vol.3,ISSN-L: 2223-9553.

Ncanywa T. and Masoga M. M. (2018). Can public debt stimulate public investment and economic growth in South Africa? Cogent Economics \& Finance, 6: 1516483. https://doi.org/10.1080/23322039.2018.1516483

Ndubuisi P. (2017). Analysis of the Impact of External Debt on Economic Growth in an Emerging Economy: Evidence from Nigeria. International Multi-disciplinary Journal, Bahir Dar, Ethiopia. VOL. 11, e-ISSN 2070-0083.

Njimanted, G. F. and Mukete, E. M. (2013). Public Expenditure and Private Investment in Cameroon: A Vector Autoregressive Approach. Journal of Emerging Issues in Economics, Finance and Banking (JEIEFB). Vol.2, pp. 818-832.

Njimanted, G. F., Mukete, E. M. and Forbe, H. N.(2015). "External Debt, Domestic Investment and Economic Growth in Cameroon" A system Estimation Approach. Journal of Economics Bibliography, Vol. 1, pp. 3-16.

Ogunmuyiwa, M.S. (2011).Does External Debt Promote Economic Growth in Nigeria? Current Research Journal of Economic Theory 3(1): 29-35.

Olowofeso, Emmanuel O.; Adeleke, Abiola O.; Udoji and Anthony O. (2015): Impact of private sector credit on economic growth in Nigeria, CBN Journal of Applied Statistics, Vol.06, pp. 81-101

Onakoya A. B. and Ogunade A. O. (2017). External Debt and Nigerian Economic Growth Connection: Evidence from Autoregressive Distributed Lag Approach. Journal of Economics and Development Studies, Vol. 5, pp. 66-78.

Ouattara B. (2004).Modelling the Long Run Determinants of Private Investment in Senegal .The University of Manchester.

Prasert C., Kanchana C., Chukiat C. and Monekeo K. (2015). Money Supply Influencing on Economic Growth-wide Phenomena of AEC Open Region. Procedia Economics and Finance, Vol. 24, pp. $108-115$.

Saifuddin Md. (2016). Public Debt and Economic Growth: Evidence from Bangladesh. Global Journal of Management and Business Research: Vol. 16, e-ISSN: 2249-4588

Shabbir S. (2013). Does External Debt Affect Economic Growth: Evidence from Developing Countries. State Bank of Pakistan Working Paper Series No.63, I.I. Chundrigar Road, Karachi, Pakistan

Shahid M. (2014). Impact of Labour Force Participation on Economic Growth in Pakistan. Journal of Economics and Sustainable Development, Vol.5, No.11, e-ISSN 22222855. 
Stock J. H. and Watson M. W. (1993). A Simple Estimator of Cointegrating Vectors In Higher Order Integrated Systems. Econometrica, Vol. 61, No. 4 , 783-820

World Bank (2018). Cameroon Public Expenditure Review: Aligning Public Expenditure with the Goals of Vision 2035.

World Bank (2019). International Debt Statistics. Washington DC 20433

\section{Copyrights}

Copyright for this article is retained by the author(s), with first publication rights granted to the journal.

This is an open-access article distributed under the terms and conditions of the Creative Commons Attribution license (http://creativecommons.org/licenses/by/4.0/) 